\title{
Use of Flaming to Control Weeds in 'Patriot' Hybrid Bermudagrass
}

\author{
Luisa Martelloni, Lisa Caturegli, Christian Frasconi, \\ Monica Gaetani, Nicola Grossi, Simone Magni, Andrea Peruzzi, \\ Michel Pirchio, Michele Raffaelli, Marco Volterrani, and \\ Marco Fontanelli ${ }^{1}$
}

AdDitional INDEX WORDs. Cynodon dactylon $\times$ Cynodon transvaalensis, flame weeding, green-up, nonchemical, thermal methods, turfgrass management

Summary. Flaming could be an alternative to the use of chemical herbicides for controlling weeds in turfgrass. In fact, the European Union has stipulated that chemical herbicides should be minimized or prohibited in public parks and gardens, sports and recreational areas, school gardens, and children's playgrounds. The aim of this research was to test different doses of liquefied petroleum gas (LPG) to find the optimal flaming dose that keeps a 'Patriot' hybrid bermudagrass (Cynodon dactylon $\times$ Cynodon transvaalensis) turf free of weeds during spring green-up, but also avoids damaging the grass. Five LPG doses $\left(0,29,48,71\right.$, and $\left.100 \mathrm{~kg} \cdot \mathrm{ha}^{-1}\right)$ were applied in a broadcast manner over the turf experimental units using a selfpropelled flaming machine. This equipment is commercially available and usable by turfgrass managers. Treatments were applied three times during the spring to allow the maximum removal of weeds from the turfgrass. Data on weed coverage, density, biomass, and turfgrass green-up were collected and analyzed. Results showed that 3 weeks after the last flaming, the greatest LPG doses used (i.e., 71 and $100 \mathrm{~kg} \cdot \mathrm{ha}^{-1}$ ) ensured the least amount of weeds (range, 5-16 weeds $/ \mathrm{m}^{2}$ ) of low weight (range, 7$60 \mathrm{~g} \cdot \mathrm{m}^{-2}$ ) and a low weed cover percentage (range, $1 \%$ to $5 \%$ ), whereas the green turfgrass coverage was high (range, $82 \%$ to $94 \%$ ). At the end of the experiment, the main weed species were horseweed (Conyza canadensis), field bindweed (Convolvulus arvensis), narrow-leaved aster (Aster squamatus), and black medic (Medicago lupulina). Flame weed control is a promising technique to conduct weed control in turfgrass. Further studies could be conducted to investigate the use of flaming in other species of warm-season turfgrasses.

$\mathrm{T}$ urfgrass is an integral and significant part of the landscape, and enhances its beauty when established and managed properly. Weed control in turfgrass is typically based on the use of chemical herbicides (Raikes et al., 1994). Using nonchemical means would reduce dependence on synthetic pesticides (Busey, 2003). Flame weeding could be an alternative to the use of selective herbicides and would also eliminate the risk of chemical residues in the turfgrass. This is in accordance with the European Union, which requires member states to minimize or prohibit chemical herbicides in public parks and gardens, sports and

Department of Agriculture, Food and Environment, University of Pisa, 56124 Pisa, Italy

This study was part of the "Tecnologie innovative per una gestione efficiente ed eco-compatibile dei tappeti erbosi" project, funded by the University of Pisa (Progetti di Ricerca di Ateneo, 2016).

${ }^{1}$ Corresponding author. E-mail: marco.fontanelli@ unipi.it.

https://doi.org/10.21273/HORTTECH04177-18 recreational areas, school gardens and children's playgrounds, as well as in the close vicinity of healthcare facilities (European Union, 2009).

The response of plants to flaming varies according to species, growth stage, leaf surface moisture, flaming dose, and temperature of the flame and air (Ulloa et al., 2010). Regardless of the growth stage, broadleaf weeds are more susceptible to flaming than grass species. Plant survival after flaming is largely dependent on the plant's ability to regrow. The annual broadleaf generally desiccates completely a few days after flaming, whereas the grassy species generate new leaves after 1 or 2 weeks (Ulloa et al., 2010). These considerations justify the investigation concerning the use of flaming as a weed control strategy in turfgrasses.

The presence of weeds in turfgrass depends on the competitive ability of the turf (Watschke and Engel, 1994). Hybrid bermudagrass is a warm-season grass species used in warm/temperate regions of the world for lawns and sports turfs (Magni et al., 2014 b). It is particularly adaptable to warm temperatures and drought, is tolerant to wear and tear, and is also competitive against weeds. Hybrid bermudagrass has excellent heat tolerance and recovery properties resulting from the abundance of stolons and rhizomes (Adamipour et al., 2016; McCarty and Miller, 2002; Volterrani et al., 1997).

The tolerance of 'Patriot' hybrid bermudagrass to flaming was tested in laboratory conditions (Fontanelli et al., 2017). Early-growth-stage plants were transplanted into trays and flamed on a test bench. Results showed that the plants were tolerant (no injury) to LPG doses of about 30 to $40 \mathrm{~kg} \cdot \mathrm{ha}^{-1}$. Injury occurred for doses greater than $40 \mathrm{~kg} \cdot \mathrm{ha}^{-1}$. This suggested that in mature, established turfgrasses, which have a network of rhizomes and stolons under the ground, the doses tolerated are likely to be greater because flaming can kill only the aerial part of the plant, and a mature turf can regrow from reserve organs (Fontanelli et al., 2017).

No information is available on the effects of flaming for controlling weeds on a mature turfgrass of ' $\mathrm{Pa}$ triot' hybrid bermudagrass. The aim of this study was to test flaming in 'Patriot' hybrid bermudagrass for weed control. This would allow

\begin{tabular}{llll}
\hline $\begin{array}{l}\text { Units } \\
\begin{array}{l}\text { To convert U.S. to SI, } \\
\text { multiply by }\end{array}\end{array}$ & U.S. unit & SI unit & $\begin{array}{l}\text { To convert SI to U.S., } \\
\text { multiply by }\end{array}$ \\
\hline 0.4047 & $\mathrm{acre}(\mathrm{s})$ & $\mathrm{ha}$ & 2.4711 \\
0.3048 & $\mathrm{ft}$ & $\mathrm{m}$ & 3.2808 \\
0.0929 & $\mathrm{ft}^{2}$ & $\mathrm{~m}^{2}$ & 10.7639 \\
2.54 & inch $(\mathrm{es})$ & $\mathrm{cm}$ & 0.3937 \\
25.4 & inch $(\mathrm{es})$ & $\mathrm{mm}$ & 0.0394 \\
1.1209 & $\mathrm{lb} / \mathrm{acre}$ & $\mathrm{kg} \cdot \mathrm{ha}^{-1}$ & 0.8922 \\
1.6093 & $\mathrm{mph}$ & $\mathrm{km} \cdot \mathrm{h}^{-1}$ & 0.6214 \\
33.9057 & $\mathrm{Oz} / \mathrm{yard}^{2}$ & $\mathrm{~g} \cdot \mathrm{m}^{-2}$ & 0.0295 \\
0.0069 & $\mathrm{psi}$ & $\mathrm{MPa}$ & 145.0377 \\
$\left({ }^{\circ} \mathrm{F}-32\right) \div 1.8$ & ${ }^{\circ} \mathrm{F}$ & ${ }^{\circ} \mathrm{C}$ & $\left({ }^{\circ} \mathrm{C} \times 1.8\right)+32$
\end{tabular}

Hortlechnology · December 2018 28(6) 
turfgrass managers to use flaming as a substitute for chemical herbicide.

\section{Materials and methods}

Flaming Machine. Flaming was conducted using a self-propelled machine designed and built at the University of Pisa (Pisa, Italy). This machine was used previously for weed control in urban contexts (Raffaelli et al., 2013). The forward speed can be increased from 1 up to $5 \mathrm{~km} \cdot \mathrm{h}^{-1}$. The machine was equipped with five $25-\mathrm{cm}$-wide rod burners with an external nozzle (diameter, $1.1 \mathrm{~mm}$ ) (Raffaelli et al., 2015) placed in front of a small frame, for a working width of $125 \mathrm{~cm}$. All the burners can be adjusted by varying the height and inclination with respect to the soil surface. In the current experiment, the burners were set at a height of 7 $\mathrm{cm}$ at an angle of $45^{\circ}$ to the ground to allow the maximum length of the flame on the turfgrass surface (Fig. 1). The machine was equipped with a heat exchange system. Two LPG tanks are placed inside a hopper that contains water. The water is heated by means of the exhaust gas, which passes through a copper tube inside the hopper.

The LPG doses used during the experiment were $0,29,48,71$, and 100 $\mathrm{kg} \cdot \mathrm{ha}^{-1}$. These doses were obtained by maintaining the LPG pressure constant at $0.25 \mathrm{MPa}$ and by varying the forward speed $(4.73,2.87,1.93$, and 1.37 $\mathrm{km} \cdot \mathrm{h}^{-1}$, respectively). The theoretical working capacities were $0.17,0.24$, 0.35 , and 0.59 ha $\cdot \mathrm{h}^{-1}$ when the doses of $29,48,71$, and $100 \mathrm{~kg} \cdot \mathrm{ha}^{-1}$ were used, respectively. These LPG doses were chosen based on weed species and stage of development observed at the beginning of the experiment, and on previous experience in the choice of LPG doses for controlling weeds (Frasconi et al., 2017; Martelloni et al., 2016, 2017; Peruzzi et al., 2017).

SITE DESCRIPTION, EXPERIMENTAL DESIGN, AND FLAMING TREATMENTS. The experiment was conducted in Spring 2016 at the experimental farm of the Department of Agriculture, Food and Environment of the University of Pisa [San Piero a Grado, Pisa, Italy (lat. $43^{\circ} 40^{\prime} \mathrm{N}$, long. $10^{\circ} 19^{\prime} \mathrm{E}$; elevation, $6 \mathrm{~m})$ ] on a mature stand of 'Patriot' hybrid bermudagrass. The turfgrass was established in 2011 on a calcaric fluvisol (coarse-silty, mixed, thermic, typic xerofluvents), with a $\mathrm{pH}$ of 7.8 and $2.2 \%$ organic matter.

Fertilization of the turfgrass consisted of the application of 100 $\mathrm{kg} \cdot \mathrm{ha}^{-1}$ nitrogen $(\mathrm{N})$ in Mar. 2016 using a centrifugal spreader. Ammonium sulfate $(2 \mathrm{IN}-0 \mathrm{P}-0 \mathrm{~K})$ was used as the $\mathrm{N}$ source. The turfgrass was not irrigated. The amount of precipitation was $41.2 \mathrm{~mm}$ in April and
$82.2 \mathrm{~mm}$ in May (total amount from February to May, $370.8 \mathrm{~mm}$ ) (Fig. 2). The turfgrass was not mowed during the experiment to observe only the effect of different LPG doses of flaming.

At the start of the experiment (13 Apr. 2016), the weeds identified in the turfgrass were narrow-leaved aster, field mouse-ear (Cerastium

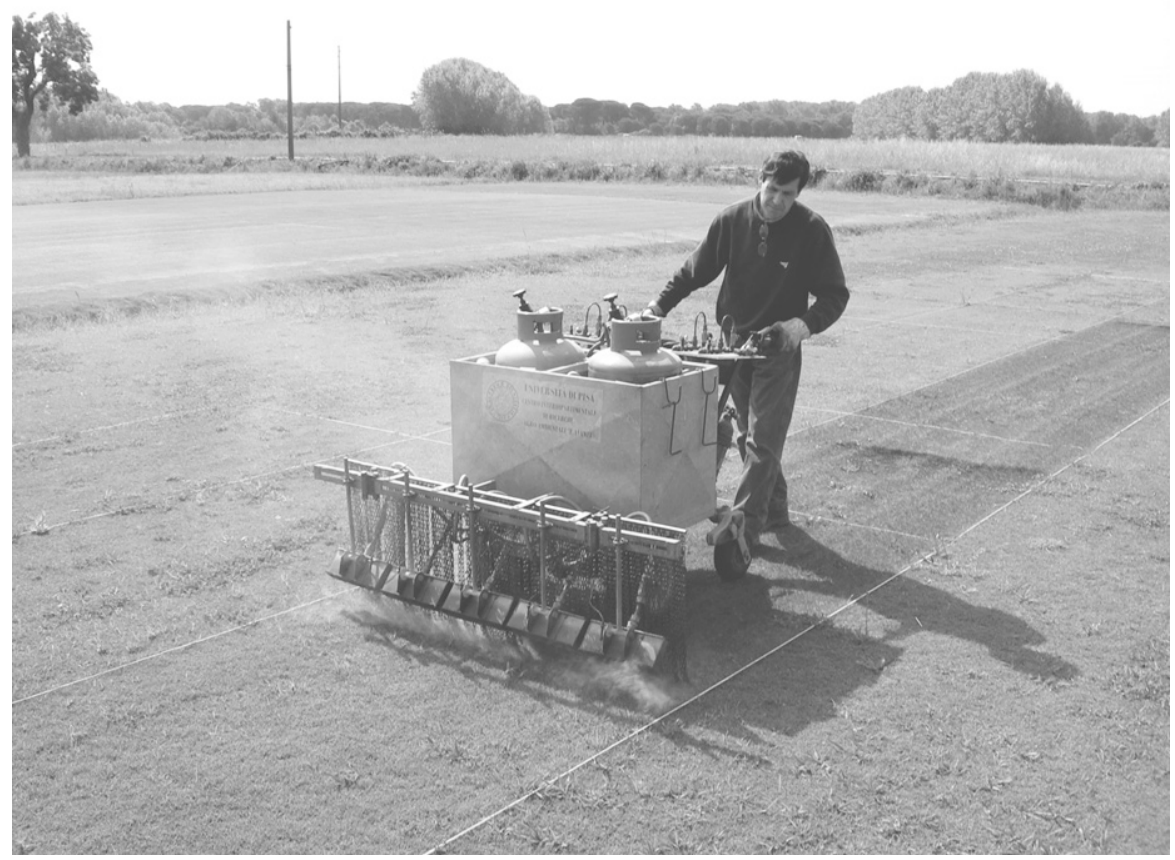

Fig. 1. The self-propelled flaming machine operating on 'Patriot' hybrid bermudagrass turf.

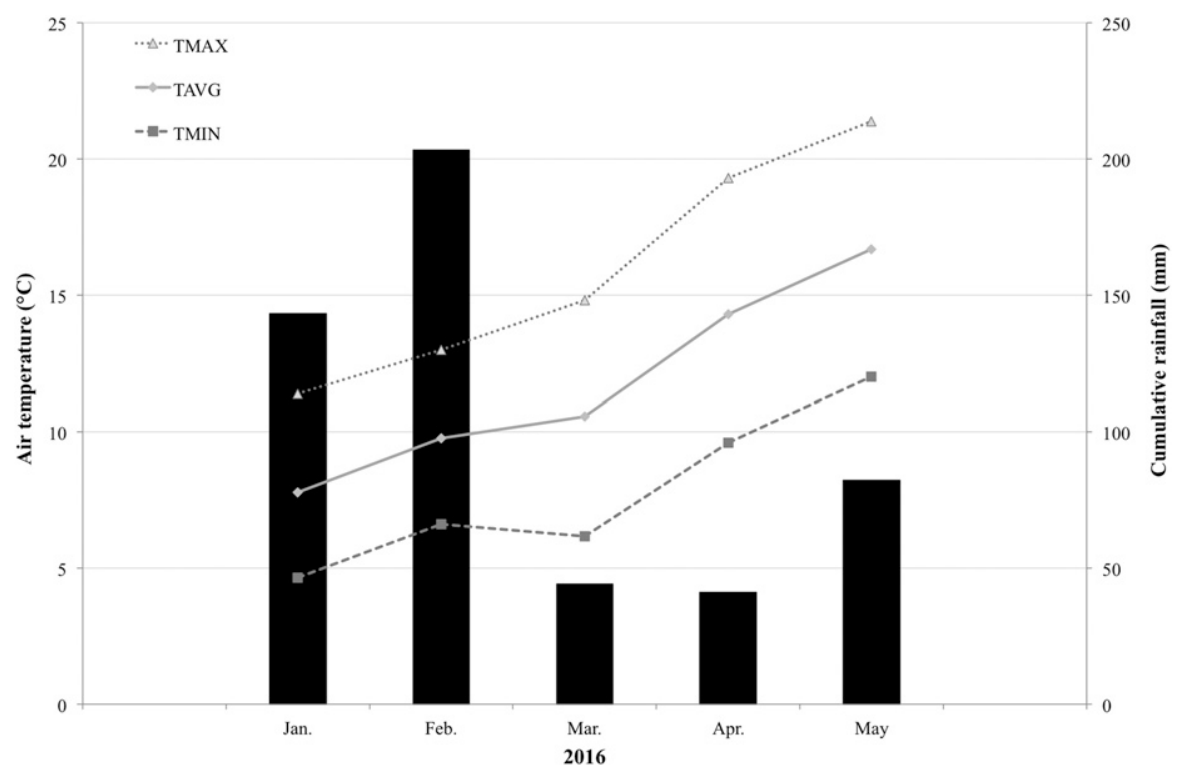

Fig. 2. Monthly (Jan. to May 2016) cumulated precipitation, and monthly average (TAVG), maximum (TMAX), and minimum (TMIN) temperature recorded by the meteorological station at San Piero a Grado (Pisa, Italy). $\left(1.8 \times{ }^{\circ} \mathrm{C}\right)+32={ }^{\circ} \mathrm{F}$, $1 \mathrm{~mm}=0.0394$ inch . 
arvense), field bindweed, creeping thistle (Cirsium arvense), black medic, hawkweed oxtongue (Picris hieracioides), foxtail millet (Setaria italica), common sowthistle (Sonchus oleraceus), dandelion (Taraxacum officinale), white clover (Trifolium repens), and birdeye speedwell (Veronica persica), all at the cotyledonary growth stage. The prevalent weeds were black medic and foxtail millet.

The average temperature recorded was $14^{\circ} \mathrm{C}$ in April and $17^{\circ} \mathrm{C}$ in May (Fig. 2). Warm-season turfgrasses enter dormancy during the fall, at soil temperatures below $10{ }^{\circ} \mathrm{C}$, and break dormancy when soil temperatures rise above this level in the spring (Schiavon et al., 2011).

The experimental design was a randomized block design with three blocks. Flaming was conducted three times, in the period of time when weeds started growing and the turfgrass started green-up. Treatments consisted of the application of five different LPG doses (0, 29, 48, 71, and $100 \mathrm{~kg} \cdot \mathrm{ha}^{-1}$ ) for each block, for a total of 15 experimental units. Experimental unit size was $4 \times 1.25 \mathrm{~m}$ $\left(5 \mathrm{~m}^{2}\right)$. Treatments were repeated three different times (on 13 Apr. 2016, 28 Apr. 2016, and 10 May 2016) per experimental unit (Fig. 3).

Data collection. Data regarding weed cover and density were collected before the first flaming (the same day) and after each of the three flaming treatments. These data collection days were the same as those for the turfgrass green-up assessment, which was conducted $14 \mathrm{~d}$ after the first flaming (maximum potential recovery time between the first and the second flaming), $7 \mathrm{~d}$ after the second flaming (midway between the second and third flaming), and $21 \mathrm{~d}$ after the third flaming (when some of the experimental units first reached the $90 \%$ green-up threshold). Therefore, data collection was conducted on 27 Apr. 2016, 5 May 2016, and 31 May 2016. Weed dry biomass was collected 21 $\mathrm{d}$ after the third flaming; after that, the other data were recorded.

Weed coverage data were collected by using a custom-built reference grid consisting of a $30 \times 30-\mathrm{cm}$ frame containing 100 squares of $3 \times 3$ $\mathrm{cm}$. Each square covered by weeds corresponded to $1 \%$ weed cover. Weed density data were collected by counting weeds within the same frame. For each

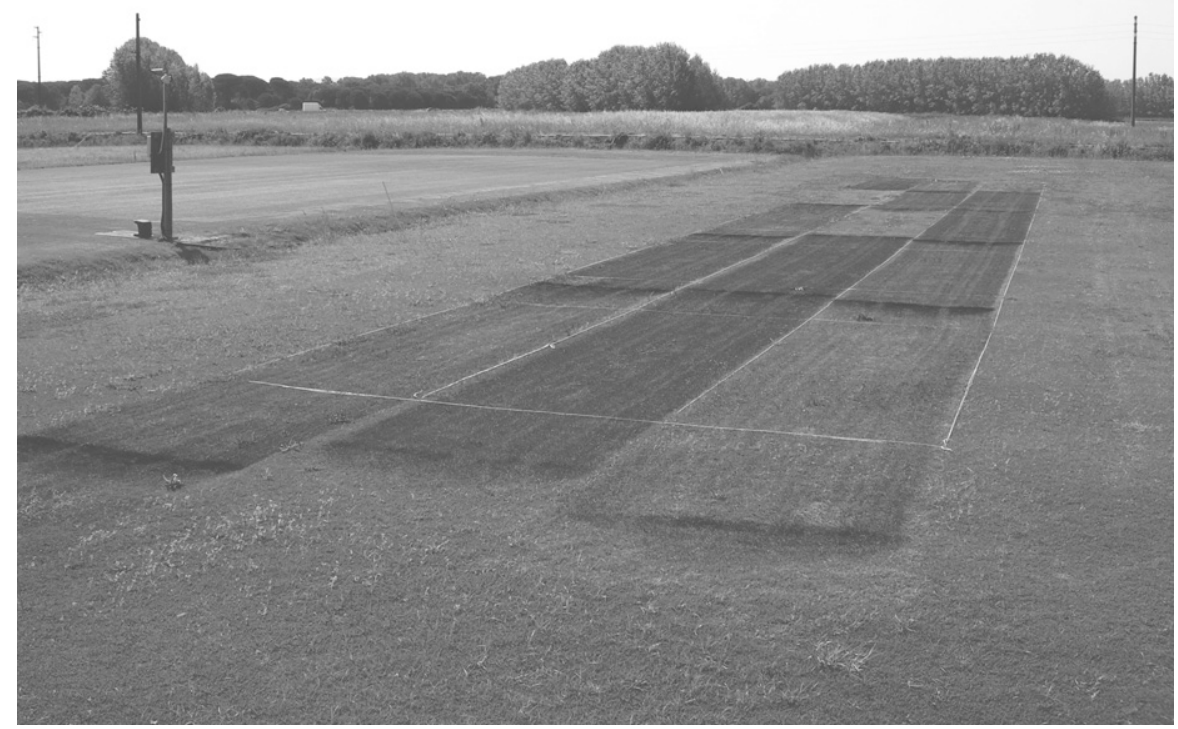

Fig. 3. Overview of the experimental field after the third flaming treatment (10 May 2016) on 'Patriot' hybrid bermudagrass turf. The injured turfgrass recovered after 3 weeks.

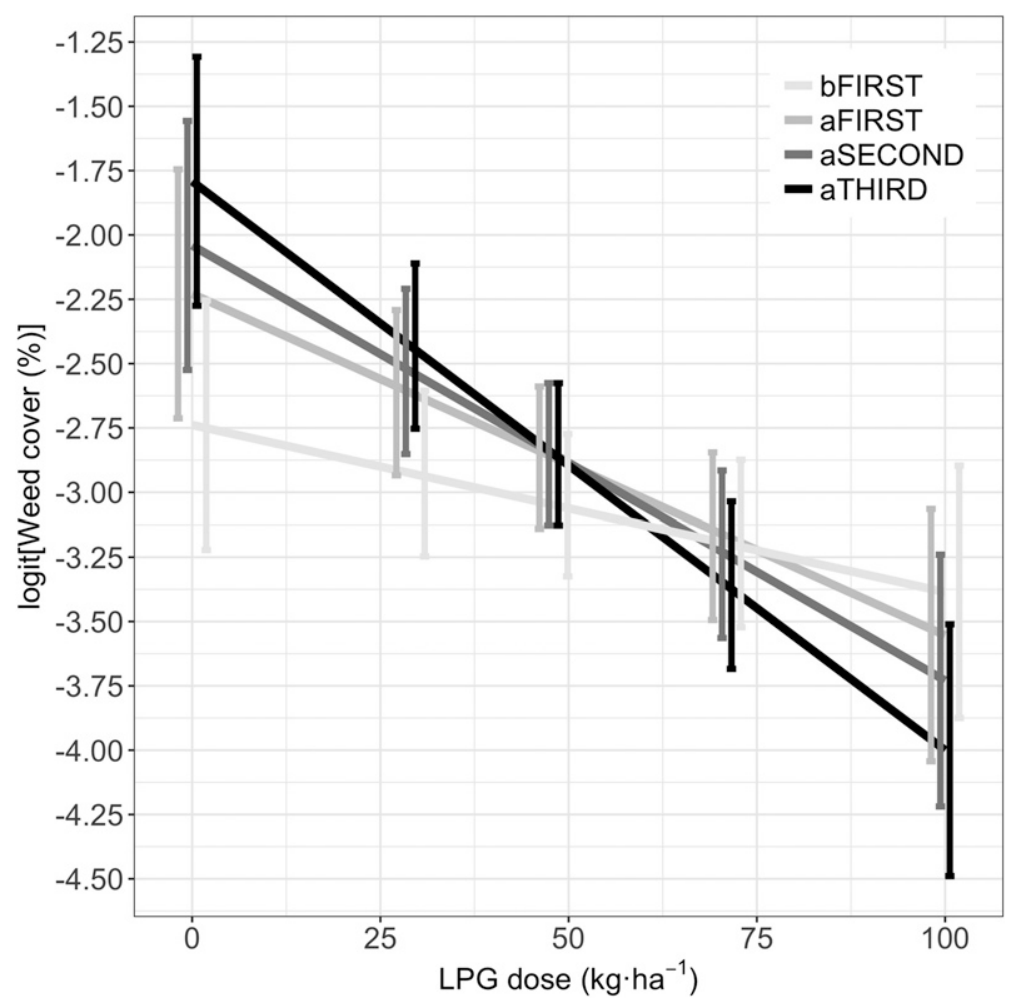

Fig. 4. Effect plot of weed cover (logit transformed) on 'Patriot' hybrid bermudagrass turf and $95 \%$ confidence intervals estimated as a function of the liquefied petroleum gas (LPG) doses used $\left(0,29,48,71\right.$, and $\left.100 \mathrm{~kg} \cdot \mathrm{ha}^{-1}\right)$ for controlling weeds on day 4 of data collection. bFIRST, weed cover before the first flaming (the same day); aFIRST, $14 \mathrm{~d}$ after the first flaming; aSECOND, $7 \mathrm{~d}$ after the second flaming; aTHIRD, $21 \mathrm{~d}$ after the third flaming. Akaike information criterion $($ AIC) value $=293.3$, Bayesian information criterion $(B I C)$ value $=346.2$; $1 \mathrm{~kg} \cdot \mathrm{ha}^{-1}=0.8922 \mathrm{lb} /$ acre . 
experimental unit, two subsamples were collected. Weeds were separated by species during each count; however, only the total weed number was analyzed. Weed density was reported as plants per square meter. Data regarding weed coverage and density were always collected in the same area. Weed dry biomass was collected by cutting weeds without roots from a $1-\mathrm{m}^{2}$ are in each experimental unit and then drying them at $105{ }^{\circ} \mathrm{C}$ to a constant weight. Green-up was evaluated by visual rating in terms of the percentage of green turfgrass coverage on the total area of each experimental unit. A rating scale of $0 \%$ (no turfgrass coverage) to $100 \%$ (total experimental unit covered by the turfgrass) was used.

Statistical analysis. Data normality was established using the Shapiro-Wilk test. Other tests consisted of Student's $t$ test to verify that the mean of the errors was not significantly different from zero, the Breusch-Pagan for homoscedasticity, and the Durbin-Watson test for serial correlation.

The weed density data followed a Poisson distribution (count data) and were modeled in a generalized linear mixed model using $\mathrm{R}$ software ( $\mathrm{R}$ Core Team, 2016) assessing the Poisson distribution by using the R extension package lme4 [Fitting Linear Mixed-Effects Models Using lme4 (Bates et al., 2015)]. The LPG doses and the day of data collection (repeated measures: 27 Apr. 2016, 5 May 2016, and 31 May 2016) were the fixed factors. The random factor was "1+ day of data collection|blocks:replicates" to allow the slope of the day of the data collection variable to vary by replicates within blocks. The model ran a log transformation. Weed coverage and turfgrass green-up data were modeled in a linear mixed model, setting a logit transformation in $\mathrm{R}$ software using the extension package "ImerTest" [Tests in Linear Mixed Effects Models (Kuznetsova et al., 2016)].

Liquefied petroleum gas doses and the day of data collection were the fixed factors. The random factor of weed cover was " $l+$ day of data collection|blocks:replicates" to allow the slope of the day of data collection variable to vary by replicates within blocks. The random factor of the turfgrass green-up was " $l+$ day of data collection|blocks" to allow the slope of the day of data collection variable to vary by blocks. Weed dry biomass data were modeled in a linear mixed model in $\mathrm{R}$ software using lmerTest. LPG dose was the fixed factor; the blocks, random factors. An analysis of variance was run for each model. The analysis of deviance was run for the model that followed the Poisson distribution.

The extension package "effects" [Effect Displays for Linear, Generalized Linear, and Other Models (Fox, 2003)] was used to estimate the mean values and SEs (and inverse transformations) of the dependent variables obtained from the models at the different LPG doses used and for the different days of data collection. The pairwise comparisons between mean values were computed by estimating the $95 \%$ confidence interval (CI) of the difference between the values. If the resulting 95\% CI of the difference between values did not cross the value zero, the null hypothesis that the compared values were similar was rejected.

The extension package "ggplot2" [Elegant Graphics for Data Analysis (Wickham, 2009)] was used to plot graphs.

\section{Results}

WeEd Coverage. Analysis of variance of the weed coverage model showed there was a significant effect of the dose, of the day of data collection, and their interaction $(P<0.001$, $=0.023$, and $=0.022$, respectively). The Akaike information criterion (AIC) of the model was 293.3 and the Bayesian information criterion (BIC) was 346.2. The effect plot is shown in Fig. 4. Means and SES of the weed coverage logit-transformed (and inverse-transformed values) estimated from the model as a function of the different LPG doses used and on day 4 of data collection are reported in Table 1.

At all the LPG doses used, weed coverage remained constant after the three flaming treatments, whereas in the nontreated control there was a significant $(8.216 \% \pm 3.156 \%)$ increase in weed coverage. In general, the least values of weed coverage were observed when the greatest LPG dose was used $\left(100 \mathrm{~kg} \cdot \mathrm{ha}^{-1}\right)$. Before the first flaming, weed coverage was

Table 1. Mean values and sEs of the weed cover logit-transformed estimated from the model as a function of the different liquefied petroleum gas (LPG) doses used $\left(0,29,48,71\right.$, and $\left.100 \mathrm{~kg} \cdot \mathrm{ha}^{-1}\right)$ for controlling weeds on a mature turfgrass of 'Patriot' hybrid bermudagrass on day 4 of data collection. Inverse-transformed means and $95 \%$ confidence intervals (CIs) are reported.

\begin{tabular}{|c|c|c|c|c|c|}
\hline \multirow{2}{*}{$\begin{array}{l}\text { LPG dose } \\
\left(\mathrm{kg} \cdot \mathrm{ha}^{-1}\right)^{\mathrm{z}}\end{array}$} & \multirow{2}{*}{$\begin{array}{l}\text { Day of data } \\
\text { collection }^{\mathrm{y}}\end{array}$} & \multirow{2}{*}{$\begin{array}{c}\text { Logit } \\
{\left[\begin{array}{c}\text { weed cover }(\%)] \\
(\text { mean } \pm S E)\end{array}\right.}\end{array}$} & \multicolumn{3}{|c|}{ Weed cover $(\%)^{x}$} \\
\hline & & & Mean & Lower 95\% CI & Upper 95\% CI \\
\hline 0 & bFIRST & $-2.74 \pm 0.23$ & 6.07 & 3.93 & 9.28 \\
\hline 0 & aFIRST & $-2.23 \pm 0.25$ & 9.72 & 6.19 & 14.94 \\
\hline 0 & aSECOND & $-2.04 \pm 0.25$ & 11.50 & 7.31 & 17.64 \\
\hline 0 & aTHIRD & $-1.79 \pm 0.26$ & 14.29 & 9.10 & 21.74 \\
\hline 29 & bFIRST & $-2.93 \pm 0.17$ & 5.09 & 3.72 & 6.93 \\
\hline 29 & aFIRST & $-2.61 \pm 0.19$ & 6.83 & 4.82 & 9.59 \\
\hline 29 & aSECOND & $-2.53 \pm 0.19$ & 7.38 & 5.15 & 10.46 \\
\hline 29 & aTHIRD & $-2.43 \pm 0.20$ & 8.08 & 5.58 & 11.56 \\
\hline 48 & bFIRST & $-3.05 \pm 0.15$ & 4.53 & 3.41 & 5.98 \\
\hline 48 & aFIRST & $-2.87 \pm 0.17$ & 5.39 & 3.90 & 7.41 \\
\hline 48 & aSECOND & $-2.85 \pm 0.18$ & 5.46 & 3.90 & 7.61 \\
\hline 48 & aTHIRD & $-2.87 \pm 0.17$ & 5.46 & 3.84 & 7.71 \\
\hline 71 & bFIRST & $-3.20 \pm 0.17$ & 3.93 & 2.85 & 5.38 \\
\hline 71 & aFIRST & $-3.17 \pm 0.19$ & 4.03 & 2.82 & 5.74 \\
\hline 71 & aSECOND & $-3.24 \pm 0.20$ & 3.77 & 2.60 & 5.45 \\
\hline 71 & aTHIRD & $-3.36 \pm 0.20$ & 3.36 & 2.28 & 4.93 \\
\hline 100 & bFIRST & $-3.39 \pm 0.23$ & 3.28 & 2.09 & 5.11 \\
\hline 100 & aFIRST & $-3.55 \pm 0.25$ & 2.78 & 1.72 & 4.48 \\
\hline 100 & aSECOND & $-3.73 \pm 0.26$ & 2.34 & 1.43 & 3.82 \\
\hline 100 & aTHIRD & $-4.00 \pm 0.26$ & 1.80 & 1.08 & 2.97 \\
\hline
\end{tabular}

${ }^{\mathrm{z}} 1 \mathrm{~kg} \cdot \mathrm{ha}^{-1}=0.8922 \mathrm{lb} /$ acre

${ }^{y_{\text {bFIRST }}}=$ weed density before the first flaming $(13$ Apr. 2016), aFIRST $=14 \mathrm{~d}$ after the first flaming $(27 \mathrm{Apr}$. 2016), aSECOND $=7 \mathrm{~d}$ after the second flaming (4 May 2016), aTHIRD $=21 \mathrm{~d}$ after the third flaming (31 May 2016).

${ }^{\mathrm{x}}$ Inverse-transformed values. 
statistically similar in all experimental units. Two weeks after the first flaming, the LPG dose of $100 \mathrm{~kg} \cdot \mathrm{ha}^{-1}$, compared with the least LPG dose used $\left(29 \mathrm{~kg} \cdot \mathrm{ha}^{-1}\right)$ and the nontreated control, led to less weed coverage. Beginning 1 week after the second flaming, the $100-\mathrm{kg} \cdot \mathrm{ha}^{-1}$ LPG dose led to less weed coverage than both 29 - and $48-\mathrm{kg} \cdot \mathrm{ha}^{-1}$ LPG doses and the nontreated control. Weed coverage was statistically similar when both 100 and $71-\mathrm{kg} \cdot \mathrm{ha}^{-1} \mathrm{LPG}$ doses were used on all days of data collection.

WEED DENSITY AND COMPOSITION. Analysis of deviance (type II Wald chi square tests) of the weed density model showed there was a significant effect of the day of data collection, and of the dose and day of data collection interaction $(P<0.001)$. The AIC of the model was 3888.3, and the BIC was 3938.4. The effect plot is shown in Fig. 5 . Means and SEs of the weed density logtransformed (and inverse-transformed values) estimated from the model as a function of the different LPG doses used and on day 4 of data collection are reported in Table 2.

In general, the effect of the LPG dose on the initial weed density was visible 3 weeks after the third flaming treatment. At this time, the weed density in the nontreated control experimental units increased significantly by about 53 weeds $/ \mathrm{m}^{2}$, compared with the number of weed plants estimated before starting the experiment, which was 21 weeds $/ \mathrm{m}^{2}$. When the LPG doses of 29 and 48 $\mathrm{kg} \cdot \mathrm{ha}^{-1}$ were used, the weed density after the third flaming was the same statistically as before the beginning of the experiment. However, when the LPG doses of 71 and $100 \mathrm{~kg} \cdot \mathrm{ha}^{-1}$ were used, the weed density after the third flaming decreased significantly by 32 and 56 weeds $/ \mathrm{m}^{2}$, respectively, compared with before flaming.

In contrast with the initial flora composition (reported in the Materials and methods section), the three flaming treatments completely removed field mouse-ear, foxtail millet and white clover, hawkweed oxtongue, common sowthistle, dandelion, and birdeye speedwell species from all the treated experimental units. Three weeks after the third flaming, when the greatest LPG dose was used $\left(100 \mathrm{~kg} \cdot \mathrm{ha}^{-1}\right)$, the weed density was consisted of horseweed only, which was not present at the start of the experiment, and field bindweed. At the same time, when the LPG

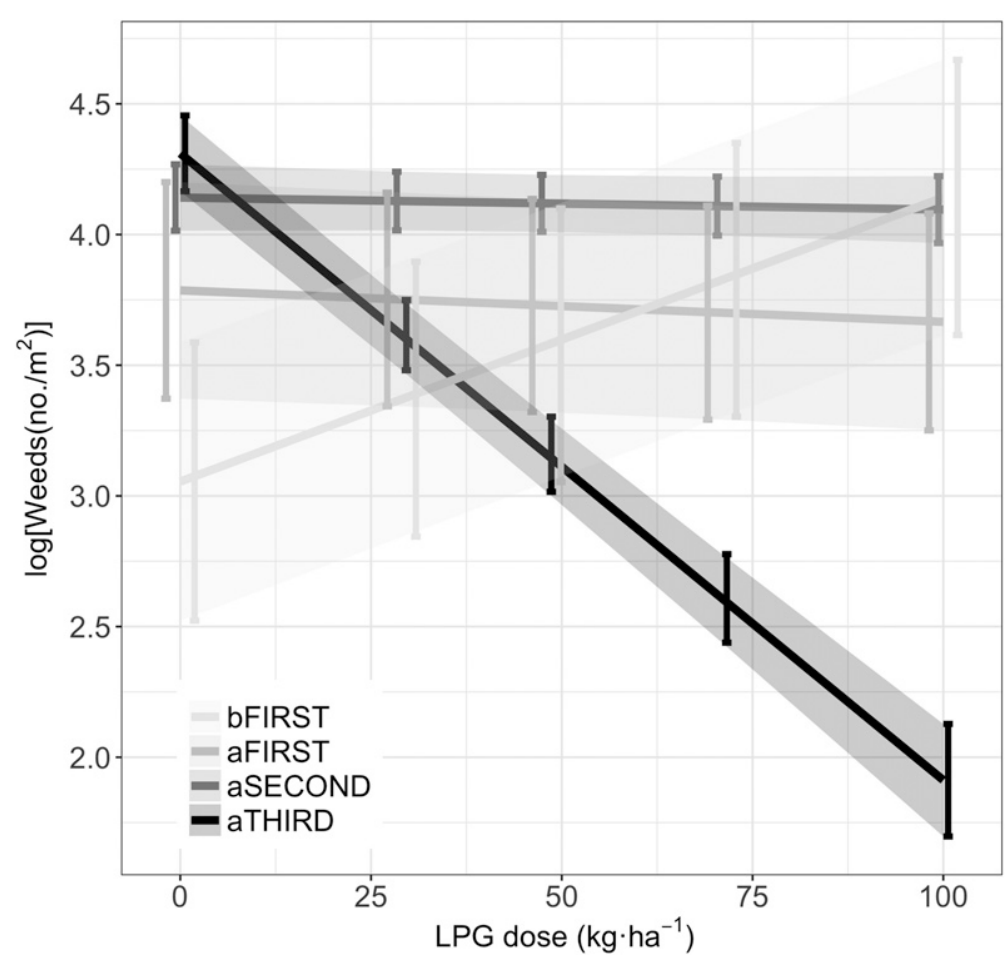

Fig. 5. Effect plot of weed density (log transformed following the Poisson distribution) on 'Patriot' hybrid bermudagrass turf and 95\% confidence intervals estimated as a function of the liquefied petroleum gas (LPG) doses used $(0,29,48,71$, and $100 \mathrm{~kg} \cdot \mathrm{ha}^{-1}$ ) for controlling weeds at the $4 \mathrm{~d}$ of data collection: bFIRST $=$ weed cover before the first flaming (the same day), aFIRST $=14 \mathrm{~d}$ after the first flaming, aSECOND $=7 \mathrm{~d}$ after the second flaming, aTHIRD $=21 \mathrm{~d}$ after the third flaming. Akaike information criterion value $=\mathbf{3 8 8 8} .3$, Bayesian information criterion value $=$ $3938.4 ; 1 \mathrm{~kg} \cdot \mathrm{ha}^{-1}=0.8922 \mathrm{lb} / \mathrm{acre}, 1$ weed $/ \mathrm{m}^{2}=0.0929$ weed $/ \mathrm{ft}^{2}$.

doses of 48 and $71 \mathrm{~kg} \cdot \mathrm{ha}^{-1}$ were used, weed density consisted of narrowleaved aster and black medic only, whereas with doses of $29 \mathrm{~kg} \cdot \mathrm{ha}^{-1}$, in addition to the previous weeds mentioned, there were horseweed, field bindweed, and creeping thistle. Prevalent weeds were narrow-leaved aster and black medic.

WEED DRY BIOMASs. Analysis of variance showed the significant effect of the dose $(P<0.001)$. The AIC of the model was 293.3 and the BIC was 346.2. The effect plot is shown in Fig. 6.

Three weeks after the third flaming, weed biomass was $26.41 \pm 10.05$ $\mathrm{g} \cdot \mathrm{m}^{-2}$ when the LPG dose of 100 $\mathrm{kg} \cdot \mathrm{ha}^{-1}$ was used. This biomass was statistically similar $(95 \% \mathrm{CI}=-2.60,44.66)$ to the biomass estimated when the LPG dose of $71 \mathrm{~kg} \cdot \mathrm{ha}^{-1}$ was used, which was $47.44 \pm 6.66 \mathrm{~g} \cdot \mathrm{m}^{-2}$. Weed biomass when the greatest LPG dose was used $\left(100 \mathrm{~kg} \cdot \mathrm{ha}^{-1}\right)$ was significantly less compared with the LPG doses of 29 and 41 $\mathrm{kg} \cdot \mathrm{ha}^{-1}(77.89 \pm 6.60$ and $64.11 \pm 5.66$ $\mathrm{g} \cdot \mathrm{m}^{-2}$, respectively), and with weed biomass estimated in the nontreated control $\left(98.92 \pm 9.94 \mathrm{~g} \cdot \mathrm{m}^{-2}\right)$ (Fig. 6).
Turfgrass green-up. Analysis of variance of the turfgrass green-up model showed there was a significant effect of the dose, of the day of data collection, and their interaction $(P<$ $0.001,=0.046$, and $=0.001$, respectively). The AIC of the model was 93.2 and the BIC was 116.7. The effect plot is shown in Fig. 7. Means and SES of the turfgrass green-up logit-transformed (and inverse-transformed values), estimated from the model as a function of the different LPG doses used, and on day 4 of data collection are reported in Table 3.

Two weeks after the first treatment, when the greatest LPG dose $\left(100 \mathrm{~kg} \cdot \mathrm{ha}^{-1}\right)$ was used, the turfgrass green-up was significantly less compared with the nontreated control $(95 \% \mathrm{CI}=0.45,1.75)$, and $\mathrm{LPG}$ doses of $29 \mathrm{~kg} \cdot \mathrm{ha}^{-1}(95 \% \mathrm{CI}=0.23$, $1.33)$ and $48 \mathrm{~kg} \cdot \mathrm{ha}^{-1}(95 \% \mathrm{CI}=0.04$, 1.10), suggesting that the greatest LPG dose delayed the recovery of the turfgrass compared with lesser doses. One week after the second treatment, the recovery of the turfgrass was slower by increasing the 
Table 2. Mean values and sEs of the weed density log-transformed estimated from the model as a function of the different liquefied petroleum gas (LPG) doses used $\left(0,29,48,71\right.$, and $\left.100 \mathrm{~kg} \cdot \mathrm{ha}^{-1}\right)$ for controlling weeds on a mature turfgrass of 'Patriot' hybrid bermudagrass on day 4 of data collection. Inverse-transformed means and $95 \%$ confidence intervals (CIs) are reported.

\begin{tabular}{|c|c|c|c|c|c|}
\hline \multirow{2}{*}{$\begin{array}{l}\text { LPG dose } \\
\left(\mathrm{kg} \cdot \mathrm{ha}^{-1}\right)^{\mathrm{z}}\end{array}$} & \multirow{2}{*}{$\begin{array}{l}\text { Day of data } \\
\text { collection }^{\mathrm{y}}\end{array}$} & \multirow{2}{*}{$\begin{array}{l}\log [\text { Weeds } \\
\left.\left(\text { no. } / \mathrm{m}^{2}\right)\right]^{z} \\
(\text { mean } \pm \text { SE })\end{array}$} & \multicolumn{3}{|c|}{ Weed $\left(\text { no. } / \mathrm{m}^{2}\right)^{\mathrm{x}}$} \\
\hline & & & Mean & Lower $95 \%$ CI & Upper 95\% CI \\
\hline 0 & bFIRST & $3.06 \pm 0.27$ & 21.22 & 12.46 & 36.13 \\
\hline 0 & aFIRST & $3.79 \pm 0.21$ & 44.10 & 29.14 & 66.73 \\
\hline 0 & aSECOND & $4.14 \pm 0.07$ & 62.90 & 55.40 & 71.42 \\
\hline 0 & aTHIRD & $4.31 \pm 0.07$ & 74.48 & 64.43 & 86.11 \\
\hline 29 & bFIRST & $3.37 \pm 0.27$ & 29.08 & 17.19 & 49.19 \\
\hline 29 & aFIRST & $3.75 \pm 0.21$ & 42.58 & 28.30 & 64.08 \\
\hline 29 & aSECOND & $4.13 \pm 0.06$ & 62.06 & 55.48 & 69.43 \\
\hline 29 & aTHIRD & $3.62 \pm 0.07$ & 37.15 & 32.48 & 42.50 \\
\hline 48 & bFIRST & $3.58 \pm 0.27$ & 35.75 & 21.18 & 60.35 \\
\hline 48 & aFIRST & $3.73 \pm 0.21$ & 41.62 & 27.69 & 62.56 \\
\hline 48 & aSECOND & $4.12 \pm 0.06$ & 61.52 & 55.16 & 68.61 \\
\hline 48 & aTHIRD & $3.16 \pm 0.07$ & 23.56 & 20.40 & 27.20 \\
\hline 71 & bFIRST & $3.83 \pm 0.27$ & 45.90 & 27.20 & 77.47 \\
\hline 71 & aFIRST & $3.70 \pm 0.21$ & 40.48 & 26.89 & 60.94 \\
\hline 71 & aSECOND & $4.11 \pm 0.06$ & 60.87 & 54.37 & 68.14 \\
\hline 71 & aTHIRD & $2.61 \pm 0.07$ & 13.57 & 11.46 & 16.07 \\
\hline 100 & bFIRST & $4.14 \pm 0.27$ & 62.92 & 37.160 & 106.52 \\
\hline 100 & aFIRST & $3.67 \pm 0.21$ & 39.09 & 25.806 & 59.21 \\
\hline 100 & aSECOND & $4.10 \pm 0.07$ & 60.06 & 52.828 & 68.27 \\
\hline 100 & aTHIRD & $1.91 \pm 0.11$ & 6.77 & 5.458 & 8.39 \\
\hline
\end{tabular}

${ }^{\mathrm{z}} 1 \mathrm{~kg} \cdot \mathrm{ha}^{-1}=0.8922 \mathrm{lb} / \mathrm{acre}, 1$ weed $/ \mathrm{m}^{2}=0.0929$ weed $/ \mathrm{ft}^{2}$

${ }^{y}$ bFIRST $=$ weed density before the first flaming $(13$ Apr. 2016), aFIRST $=14 \mathrm{~d}$ after the first flaming (27 Apr 2016), aSECOND $=7 \mathrm{~d}$ after the second flaming ( 4 May), aTHIRD $=21 \mathrm{~d}$ after the third flaming (31 May).

Inverse-transformed values.

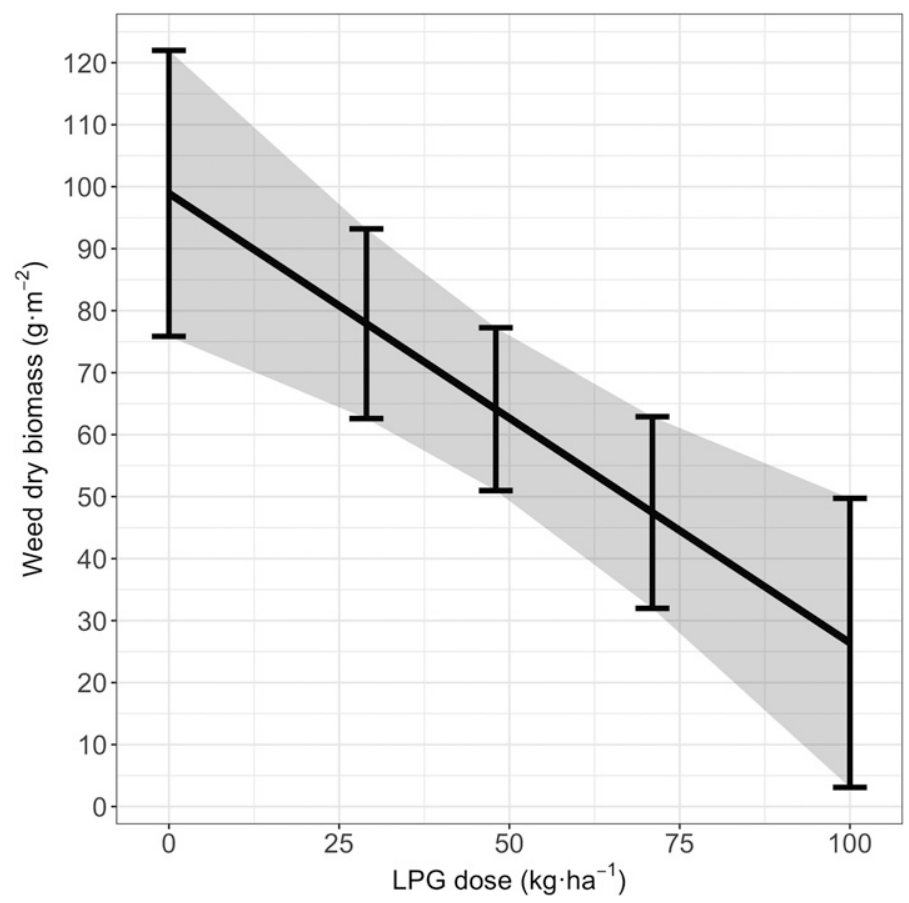

Fig. 6. Effect plot of weed biomass on 'Patriot' hybrid bermudagrass turf and $95 \%$ confidence intervals estimated as a function of the liquefied petroleum gas (LPG) doses used $\left(0,29,48,71\right.$, and $\left.100 \mathrm{~kg} \cdot \mathrm{ha}^{-1}\right)$ for controlling weeds $21 \mathrm{~d}$ after the third flaming. Akaike information criterion value $=143.2$, Bayesian information criterion value $=146.0 ; 1 \mathrm{~kg} \cdot \mathrm{ha}^{-1}=0.8922 \mathrm{lb} / \mathrm{acre}, 1 \mathrm{~g} \cdot \mathrm{m}^{-2}=0.0295 \mathrm{oz} / \mathrm{yard}^{2}$.
LPG dose, and all doses led to a statistically different turfgrass green-up percentage (Fig. 7). Three weeks after the third treatment, the turfgrass green-up was significantly greater when the LPG dose of $100 \mathrm{~kg} \cdot \mathrm{ha}^{-1}$ was used compared with the LPG doses of $48 \mathrm{~kg} \cdot \mathrm{ha}^{-1}(95 \% \mathrm{CI}=0.23$, $1.29), 29 \mathrm{~kg} \cdot \mathrm{ha}^{-1}(95 \% \mathrm{CI}=0.49$, $1.59)$, and the nontreated control $(95 \%$ CI $=0.81,2.11)$. Turfgrass green-up was statistically similar when LPG doses of 71 and $100 \mathrm{~kg} \cdot \mathrm{ha}^{-1}$ were used $(95 \% \mathrm{CI}=-0.13,0.97)$, suggesting that turfgrass recovery was greater in experimental units with less weed coverage, density and biomass.

\section{Discussion}

Better results in terms of weed control and turfgrass coverage were generally observed when the LPG doses of $7 \mathrm{l}$ and $100 \mathrm{~kg} \cdot \mathrm{ha}^{-1}$ were used. The percentage of weed coverage 3 weeks after the last flaming was less when LPG doses of $7 \mathrm{l}$ and $100 \mathrm{~kg} \cdot \mathrm{ha}^{-1}$ were used. This suggests that, when the colonization of weeds is greater (from 13 Apr. to 31 May 2016), flaming at these doses prevented the area covered by weeds from extending. During the same time, the number of weed plants when the LPG dose of $100 \mathrm{~kg} \cdot \mathrm{ha}^{-1}$ was used was less compared with the LPG dose of $71 \mathrm{~kg} \cdot \mathrm{ha}^{-1}$, whereas weed coverage and biomass were statistically similar. This suggests that fewer weeds survived at 100 $\mathrm{kg} \cdot \mathrm{ha}^{-1}$, although horseweed and field bindweed were more vigorous.

Three weeks after the third flaming, with all the LPG doses used in the experiment, seven weed species of the initial 11 had been removed completely from the turfgrass. Moreover, when the doses of 48,71 , and 100 $\mathrm{kg} \cdot \mathrm{ha}^{-1}$ were used, 9 of the 11 weed species were eliminated. With the LPG dose of $100 \mathrm{~kg} \cdot \mathrm{ha}^{-1}$, black medic, which at the start of the experiment was the most common weed present, was removed completely from experimental units. Horseweed, which at the start of the experiment was not present, was found only in experimental units where the LPG dose of $100 \mathrm{~kg} \cdot \mathrm{ha}^{-1}$ was used. Busey (2003) reviewed research papers about nonchemical weed control in hybrid bermudagrass by using mowing; but, unlike with flaming, results showed an increase in weed density and number of species. 


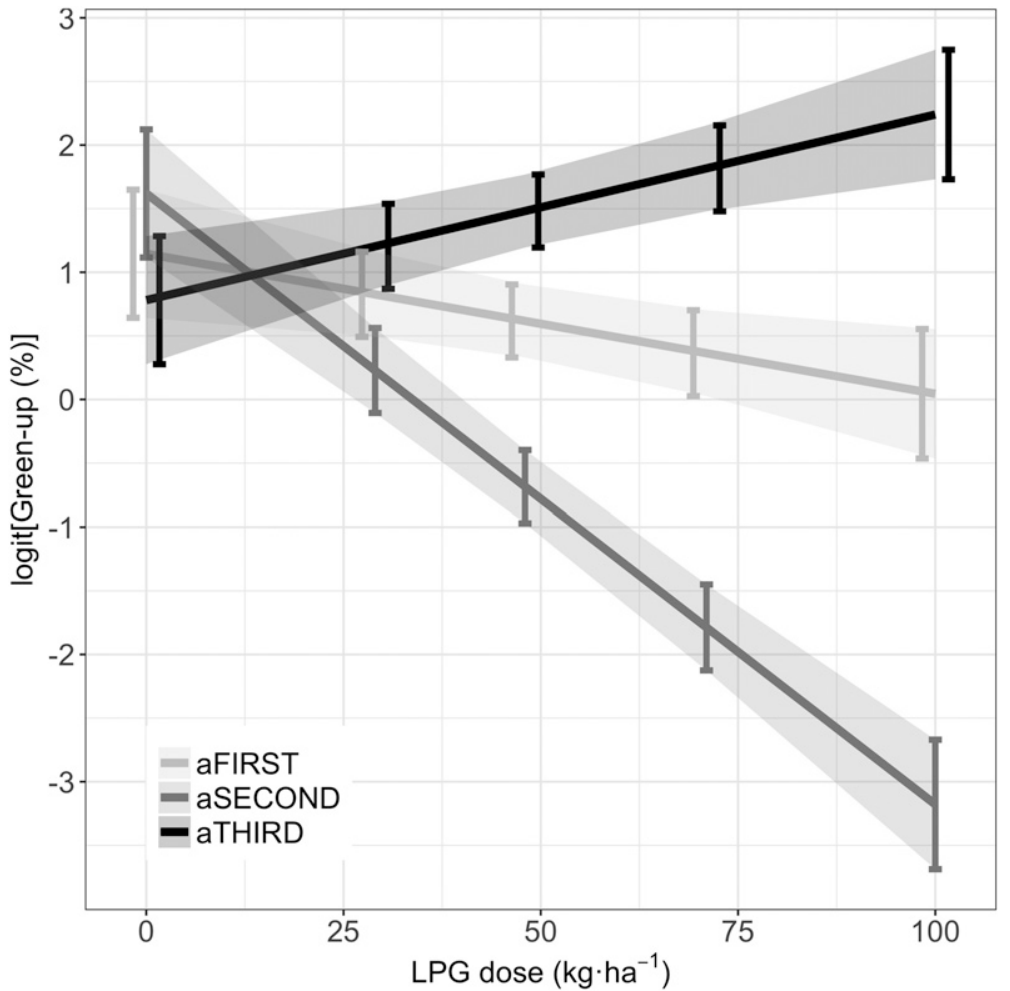

Fig. 7. Effect plot of 'Patriot' hybrid bermudagrass turfgrass green-up (logit transformed) and $95 \%$ confidence intervals estimated as a function of the liquefied petroleum gas (LPG) doses used $\left(0,29,48,71\right.$, and $\left.100 \mathrm{~kg} \cdot \mathrm{ha}^{-1}\right)$ for controlling weeds on day 3 of data collection. aFIRST, $14 \mathrm{~d}$ after the first flaming; aSECOND, $7 \mathrm{~d}$ after the second flaming; aTHIRD, $21 \mathrm{~d}$ after the third flaming. Akaike information criterion value $=93.2$, Bayesian information criterion value $=116.7$; $1 \mathrm{~kg} \cdot \mathrm{ha}^{-1}=0.8922 \mathrm{lb} /$ acre.

Table 3. Mean values and SEs of the turfgrass green-up logit-transformed estimated from the model as a function of the different liquefied petroleum gas (LPG) doses used $\left(0,29,48,71\right.$, and $\left.100 \mathrm{~kg} \cdot \mathrm{ha}^{-1}\right)$ for controlling weeds on a mature turfgrass of 'Patriot' hybrid bermudagrass, on day 3 of data collection. Inverse-transformed means and $95 \%$ confidence intervals (CIs) are reported.

\begin{tabular}{|c|c|c|c|c|c|}
\hline \multirow[b]{2}{*}{$\begin{array}{l}\text { LPG dose } \\
\left(\mathrm{kg} \cdot \mathrm{ha}^{-1}\right)^{\mathrm{z}} \\
\end{array}$} & \multirow[b]{2}{*}{$\begin{array}{c}\text { Day of data } \\
\text { collection }^{\mathrm{y}}\end{array}$} & \multirow{2}{*}{$\begin{array}{c}\text { Logit [turfgrass } \\
\text { green-up }(\%)] \\
(\text { mean } \pm \text { SE })\end{array}$} & \multicolumn{3}{|c|}{ Turfgrass green-up $(\%)^{x}$} \\
\hline & & & Mean & $\begin{array}{c}\text { Lower } \\
95 \% \text { CI }\end{array}$ & $\begin{array}{c}\text { Upper } \\
95 \% \text { CI }\end{array}$ \\
\hline 0 & aFIRST & $1.15 \pm 0.23$ & 75.87 & 66.30 & 83.40 \\
\hline 0 & aSECOND & $1.62 \pm 0.23$ & 83.47 & 75.96 & 88.98 \\
\hline 0 & aTHIRD & $0.78 \pm 0.23$ & 68.59 & 57.74 & 77.72 \\
\hline 29 & aFIRST & $0.83 \pm 0.15$ & 69.56 & 62.60 & 75.72 \\
\hline 29 & aSECOND & $0.23 \pm 0.15$ & 55.67 & 47.92 & 63.16 \\
\hline 29 & aTHIRD & $1.20 \pm 0.15$ & 76.92 & 70.95 & 81.98 \\
\hline 48 & aFIRST & $0.62 \pm 0.13$ & 64.96 & 58.66 & 70.77 \\
\hline 48 & aSECOND & $-0.68 \pm 0.13$ & 33.54 & 27.87 & 39.73 \\
\hline 48 & aTHIRD & $1.48 \pm 0.13$ & 81.48 & 77.10 & 85.17 \\
\hline 71 & aFIRST & $0.36 \pm 0.16$ & 59.00 & 51.24 & 66.34 \\
\hline 71 & aSECOND & $-1.79 \pm 0.16$ & 14.34 & 10.89 & 18.65 \\
\hline 71 & aTHIRD & $1.82 \pm 0.16$ & 86.02 & 81.79 & 89.39 \\
\hline 100 & aFIRST & $0.05 \pm 0.23$ & 51.12 & 39.43 & 62.68 \\
\hline 100 & aSECOND & $-3.18 \pm 0.23$ & 4.00 & 2.53 & 6.27 \\
\hline 100 & aTHIRD & $2.24 \pm 0.23$ & 90.38 & 85.40 & 93.78 \\
\hline
\end{tabular}

${ }^{\mathrm{z}} 1 \mathrm{~kg} \cdot \mathrm{ha}^{-1}=0.8922 \mathrm{lb} /$ acre.

${ }_{\mathrm{a}} \mathrm{aFIRST}=14 \mathrm{~d}$ after the first flaming (27 Apr. 2016), aSECOND $=7 \mathrm{~d}$ after the second flaming (4 May 2016), aTHIRD $=21 \mathrm{~d}$ after the third flaming (31 May 2016).

${ }^{\mathrm{x}}$ Inverse transformed values.
At the start of the experiment ( 13 Apr. 2016), the turfgrass started to break dormancy. This suggests that the low green-up percentages estimated both 1 and 2 weeks after the first two treatments were not completely the result of flaming, but the yellow/brown appearance of the turf was also a result of the loss of chlorophyll during the dormancy stage. Indeed, dormancy led to the total loss of the green pigment in leaves and stems during winter (Beard, 1973; Mirabile et al., 2016; Schiavon et al., 2011). The low green coverage of the turfgrass, estimated 1 and 2 weeks after flaming, and as a result of the yellow/ brown appearance of the turf caused both by the injury from flaming (when LPG doses were from 40 to $100 \mathrm{~kg} \cdot \mathrm{ha}^{-1}$ ) and winter discoloration, had recovered completely 3 weeks after the last treatment. Probably 2 weeks after the first flaming, the low turfgrass coverage was mostly the result of the partial yellow/brown appearance of the turf caused by winter dormancy, whereas 1 week after the second flaming, the low green-up of the turfgrass was mostly the result of injury caused by flaming. Doses from 0 to $25 \mathrm{~kg} \cdot \mathrm{ha}^{-1}$ of LPG were probably not enough to kill weeds, which 3 weeks after the third flaming had a greater weed coverage compared with before the first flaming. For LPG doses from 0 to 25 $\mathrm{kg} \cdot \mathrm{ha}^{-1}$, the green-up 3 weeks after the third flaming was less compared with the green-up when greatest doses were used. This was probably because, at these doses, the weeds were not killed by flaming, and did not allow the full establishment of the turfgrass also when the green-up started (i.e., about 10 May), because the weeds had already colonized the plots. Three weeks after the third flaming, the turfgrass had recovered completely from the injury caused by flaming, resulting in a greater percentage of turfgrass coverage when the greatest LPG doses (i.e., 71 and $100 \mathrm{~kg} \cdot \mathrm{ha}^{-1}$ ) were used. At this time, weeds were devitalized quite completely by the greatest LPG doses, and the turfgrass covered the ground quickly as a result of warmer temperatures and greater precipitation observed in May, thus providing few gaps in the canopy for weeds to colonize.

The most important factor distinguishing sensitive and tolerant species is not heat tolerance, but rather 
the ability of plants to recover after flaming. The greater the amount of reserve elements in the roots, the greater the plant's ability to regrow (Ascard, 1995). In addition, hybrid bermudagrass is characterized by an aggressive growth habit constituted by stolons and rhizomes full of carbohydrate reserves (Magni et al., 2014a). Flame weeding is therefore preferable in poorly irrigated 'Patriot' hybrid bermudagrass turfs for use in late spring and summer, when the turf has recovered completely, and weeds are much less likely to grow. Hybrid bermudagrass has been found to be a good competitor to weeds when the turf is fully established (Geren et al., 2009).

\section{Conclusions}

Our experiment showed that flame weed control can be used for weed control in a mature turfgrass of 'Patriot' hybrid bermudagrass in spring during the season green-up. LPG doses of 71 and $100 \mathrm{~kg} \cdot \mathrm{ha}^{-1}$ led to the greatest level of weed control. However, by using these high doses, it is necessary to pay attention not to create excessive injuries to the turfgrass, which in this experiment was able to recover after 3 weeks. Given that tolerance to flaming may vary from species to species, further studies on other warm-season turfgrass species are needed to investigate the use of flame weeding as an alternative to chemical herbicides.

\section{Literature cited}

Adamipour, N., H. Salehi, and M. Khoshkhui. 2016. Morpho-physiological alteration in common bermudagrass [Cynodon dactylon (L.) Pers.] subjected to limited irrigation and light condition. Adv. Hort. Sci. 30:141-149.

Ascard, J. 1995. Thermal weed control by flaming: Biological and technical aspects. SLU Reprocentralen, Alnarp, Sweden.

Bates, D., M. Maechler, B. Bolker, and S. Walker. 2015. Fitting linear mixed-effects models using lme4. J. Stat. Softw. 67:148 .

Beard, J.B. 1973. Turfgrass: Science and culture. Prentice Hall, Englewood Cliffs, NJ.
Busey, P. 2003. Cultural management of weeds in turfgrass: A review. Crop Sci. 43:1899-1911.

European Union. 2009. Directive 2009/ 128/EC. Offic. J. European Union 309:71-86.

Fontanelli, M., C. Frasconi, M. Raffaelli, L. Martelloni, L. Abou Chehade, and A. Peruzzi. 2017. Can flaming be performed as selective weed control treatment in turfgrass? Chem. Eng. Trans. 58:241246.

Fox, J. 2003. Effect displays in $\mathrm{R}$ for generalised linear models. J. Stat. Softw. 815:1-27.

Frasconi, C., L. Martelloni, M. Fontanelli, M. Raffaelli, P. Marzialetti, and A. Peruzzi. 2017. Thermal weed control in Photinia $\times$ Fraseri "red robin" container nurseries. Appl. Eng. Agr. 33:345-356.

Geren, H., R. Avcioglu, and M. Curaoglu. 2009. Performances of some warmseason turfgrasses under Mediterranean conditions. Afr. J. Biotechnol. 8:44694474

Kuznetsova, A., P.B. Brockhoff, and R.H.B. Christensen. 2016. lmerTest: Tests in linear mixed effects models. 26 Sept. 2018. <https://CRAN.R-project.org/ package $=$ lmerTest $>$.

Magni, S., M. Gaetani, L. Caturegli, C. Leto, T. Tuttolomondo, S. La Bella, G. Virga, N. Ntoulas, and M. Volterrani. 2014a. Phenotypic traits and establishment speed of 44 turf bermudagrass accessions. Acta Agr. Scand. Sect. B Soil Plant Sci. 64:722-733.

Magni, S., M. Gaetani, N. Grossi, L. Caturegli, S. La Bella, C. Leto, G. Virga, T. Tuttolomondo, F. Lulli, and M. Volterrani. 2014b. Bermudagrass adaptation in the Mediterranean climate: Phenotypic traits of 44 accessions. Adv. Hort. Sci. 28:29-34.

Martelloni, L., M. Fontanelli, C. Frasconi, M. Raffaelli, and A. Peruzzi. 2016. Crossflaming application for intra-row weed control in maize. Appl. Eng. Agr. 32:569-578.

Martelloni, L., M. Fontanelli, C. Frasconi, M. Raffaelli, M. Pirchio, and A. Peruzzi. 2017. Combined flamer-cultivator for weed control during the harvesting season of asparagus green spears. Span. J. Agr. Res. 15:e0203.
McCarty, L.B. and G. Miller. 2002. Managing bermudagrass turf. Ann Arbor Press, Chelsea, MN.

Mirabile, M., F. Bretzel, M. Gaetani, F. Lulli, and M. Volterrani. 2016. Improving aesthetic and diversity of bermudagrass lawn in its dormancy period. Urban For. Urban Green. 18:190-197.

Peruzzi, A., L. Martelloni, C. Frasconi, M. Fontanelli, M. Pirchio, and M. Raffaelli. 2017. Machines for non-chemical intrarow weed control in narrow and widerow crops: A review. J. Agr. Eng. 48: 57-70.

R Core Team. 2016. R: A language and environment for statistical computing. 26 Sept. 2018. <https://www.R-project. org $/>$.

Raffaelli, M., C. Frasconi, M. Fontanelli, L. Martelloni, and A. Peruzzi. 2015. LPG burners for weed control. Appl. Eng. Agr. 31:717-731.

Raffaelli, M., L. Martelloni, C. Frasconi, M. Fontanelli, and A. Peruzzi. 2013. Development of machines for flaming weed control on hard surfaces. Appl. Eng. Agr. 29:663-673.

Raikes, C., N.W. Lepp, and P.M. Canaway. 1994. Major diseases, pests and weeds of winter sports turf: II. A questionnaire survey of local authorities. J. Sports Turf Res. Inst. 70:83-99.

Schiavon, M., B. Leinauer, E. Sevastionova, M. Serena, and B. Maier. 2011. Warmseason turfgrass quality, spring greenup, and fall color retention under drip irrigation. Appl. Turfgrass Sci. 3 Sept. 2018 . <http://www.irrigatortraining. com/DripWSTurf.pdf $>$.

Ulloa, S.M., A. Datta, and S.Z. Knezevic. 2010. Tolerance of selected weed species to broadcast flaming at different growth stages. Crop Prot. 29:1381-1388.

Volterrani, M., N. Grossi, G. Pardini, S. Miele, M. Gaetani, and S. Magni. 1997. Warm season turfgrass adaptation in Italy. Intl. Turfgrass Soc. Res. J. 8:1344-1354.

Watschke, T.L. and R.E. Engel. 1994. Ecology of turfgrass weeds, p. 29-36. In: A.J. Turgeon (ed.). Turf weeds and their control. Amer. Soc. Agron, Crop Sci. Soc. Amer., Madison, WI.

Wickham, H. 2009. ggplot2: Elegant graphics for data analysis. Springer-Verlag, New York, NY. 